\title{
Effects of Rainfall Seasonality on Scarabaeinae dung Beetles in an Agriculture Habitat in South Western Ghats
}

\author{
Thomas Latha
}

\author{
Department of Science, Faculty of Science and Technology, University of Belize, Belize
}

\begin{abstract}
Scarabaeinae dung beetles are a ubiquitous group of beetles that are detritivores and provides important ecological services to the ecosystem. They are biological indicators and their community structure is affected by physical and biotic characteristics of the environment. Rainfall is an important parameter that affects these beetles. Rainfall seasonality ofdung beetles in an agriculture habitat in South Western Ghats was studied. Cow dung baited pitfall traps were used to trap dung beetles in a banana plantation during the northeast monsoon, summer and southwest monsoon season. The study showed that agriculture activities affected dung beetle community attributes in the three seasons. Abundance, species richness and diversity was lowest in the northeast monsoon season characterized by moderate rainfall and ideal environmental conditions. This was a result of agricultural practices in the region, where banana cultivationactivities peaks in the northeast monsoon season, which makes conditions unfavorablefor dung beetles to colonize the agriculture habitat during this season.
\end{abstract}

Keywords - Scarabaeinae, agriculture habitat, rainfall seasonality

\section{INTRODUCTION}

Scarabaeinae dung beetles are a ubiquitous group of beetles that are detritivores, feeding on mammalian dung, carrion and vegetable matter (Hanski and Cambefort, 1991). Through their feeding habits, they provide important ecosystem services such as nutrient recycling, soil aeration, secondary seed dispersal, reduce population of disease causing flies and helminth parasites (Nichols et al., 2008). Scarabaeinae beetles are important indicator species as their community structure is affected by changes in microclimate factors of the environment, vegetation and mammal abundance (Nichols et al., 2007).These beetles are also affected by seasonal changes in rainfall (Hanski and Cambefort, 1991), with differences in abundance and guild structure between dry and wet seasons (Andresen, 2005). Rainfall provides humidity to the soil and triggers the $\underline{\text { www.jieab.com }}$ emergence and/or the onset of activity in the beetle species (Doube, 1991; Halffter, 1991; Hanski and Cambefort, 1991). Rainfall also affects the quantity and quality of dung available to the beetles by affecting vegetation growth and abundance of mammals (Cambefort and Walter, 1991; Estrada et al., 1999).

Western Ghats in the Indian subcontinent is a biodiversity hotspot facing many threats to its ecosystem through deforestation, non-timber product harvest, construction of dams and roads (Kumar, 1993; Jha et al., 2000; Shahabuddin and Prasad, 2004). Large tracts of forest in the South Western Ghats region has been converted into plantations and agriculture habitats (Joy, 1991; Nair, 1991; Latha and Unnikrishnan, 2007). The Western Ghats strongly influences the rainfall pattern of Kerala state in the Indian subcontinent. The Kerala state is a strip of land running almost in North-South direction and is situated between the Arabian Sea on the West and the ranges of Western Ghats and Nilgiri Hills on the East, both running parallel to each other. The region is characterised by three seasons, the heavy rainy periods of southwest monsoon, moderate rainy periods of northeast monsoon and the hot summer season with scanty rains (Nathan, 2000).

There is limited information on the effects of habitat conversion and rainfall seasonality on dung beetle community attributes in South Western Ghats. In the present study, species richness, abundance and diversity of dung beetles in the southwest monsoon, northeast monsoon and summer seasons in an agriculture habitat was studied.

\section{MATERIALS AND METHODS}

\subsection{Study site}

The study region, Nelliampathi is located at a height of 467 to $1572 \mathrm{~m}$ above sea level and is spread over a total area of $82 \mathrm{sq} \mathrm{km}$ at a distance of about $52 \mathrm{~km}$ from Palghat town in Kerala state (Fig. 1). The study was carried out in Kaikatty located at $10^{\circ} 31^{\prime} \mathrm{N}$ and $76^{\circ} 40^{\prime} \mathrm{E}$, at an elevation of $960 \mathrm{~ms} 1$. The temperature of the region varied between $15^{\circ} \mathrm{C}-30^{\circ} \mathrm{C}$ and 
annual rainfall exceeds $3000 \mathrm{~mm}$ (Nair, 1991). The study habitat consisted of 920 acres of government owned agriculture land where orange, sapodilla, banana and other fruit trees are grown. The traps were set in the part of the agriculture habitat with banana plantation.

2.2 Sampling

Dung beetles were collected on a seasonal basis in May (summer season), September (southwest monsoon season) and December (northeast monsoon season) during the 2007 2008 study period. Each collection effort involved placing ten baited pitfall traps containing $200 \mathrm{~g}$ cow dung as bait, placed $50 \mathrm{~m}$ apart in the study habitat. The trap contents were collected at $12 \mathrm{~h}$ intervals (6:00-18:00h and 18:00-6:00h) for each collection effort. Collected beetles were preserved in $70 \%$ alcohol overnight and later identified to species levels using taxonomic keys and by verifying with type specimens available in the Coleoptera collections of St. Joseph's College, Devagiri, Calicut.

\subsection{Analys is}

Since the data was not normally distributed, non-parametric statistics Kruskal-Wallis $H$ test was used to test the significant levels of variation in overall abundance of beetles, Shannon diversity (H') and abundance of individual species of dung beetles with seasons. Differences with a p-value $<0.05$ was compared using Mann-Whitney Test. The beetles were classified as seasonalbeetles if they showed significant variation in abundance with seasons, and aseasonal if they did not show significant variation in abundance with seasons. Singletons were considered as rare and excluded from seasonality studies.

\section{RESULTS}

A total of eight species and 44 beetles were collected during northeast monsoon season, 17 species and 194 beetles in the summer season and 17 species and 105 beetles in the southwest monsoon seas on (Fig. 2, Table 1). Abundance of dung beetles showed significant variation with seasons $(\mathrm{H}=$ 22.373, $\mathrm{df}=2, \mathrm{p}=<0.001$ ). Pairwise comparis on of abundance showed significant variation between northeast monsoon and summer $(\mathrm{p}=<0.001)$, northeast monsoon and southwest monsoon $(p=<0.001)$, but there was no significant variation in abundance between summer and southwest monsoon $(\mathrm{p}=$ 0.177). The Shannon diversity value ( $\left.\mathrm{H}^{\prime}\right)$ for northeast monsoon season was 1.49 , summer was 2.12 and southwest monsoon was 2.28. Diversity did not vary significantly with seasons $(\mathrm{H}=4.450, \mathrm{df}=2, \mathrm{p}=0.108)$.

Eight species, all tunnelers showed significant seasonality, Caccobius meridionalis, Catharsius molossus, Copris repertus, Onthophagus furcillifer, O. laevis, O. manipurensis, O. pacificus and Paracopris davisoni (Table
1). Caccobius meridionalis, Catharsius molossus and Onthophagus furcillifer showed highest abundance in summer; Copris repertus and Onthophagus pacificus showed highest abundance in southwest monsoon. Onthophagus laevis and Paracopris davisoni were present only in southwest monsoon season; $O$. manipurensis was present only in summer. Eleven species were aseasonal tunnelers. Seasonality in six species could not be determined due to rarity in collection (Fig. 3; Table 1).

\section{DISCUSSION}

Low abundance, species richness and diversity recorded during the northeast monsoon season in the agriculture habitat in Nelliampathi is in contrast to results observed in the forest (Latha, 2019; Vinod, 2009) and agriculture habitat (Venugopal et al., 2012; Vinod, 2009) of the South Western Ghats region, where high abundance, species richness and diversity was observed in the northeast monsoon season. Dung beetle seasonality studies done in other parts of the world also show that activity is greatest during moist and minimal during dry periods and the abundance of scarab beetles increases strongly after heavy rainfall (Walter, 1985; Doube et al., 1991; Hanski and Krikken, 1991; Andresen, 2005; Batista et al., 2016).

After the heavy rainy periods of the southwest monsoon season, northeast monsoon seas on is characterized by ideal climatic conditions and plant growth. This is the time when agricultural activities reach a peak. Low abundance, species richness and diversity observed in the northeast monsoon season in the agriculture habitat of Nelliampathi region is directly related to the agricultural practices. Banana cultivation in the region is done annually and periods of heavy monsoon and severe summer is avoided for planting. This is to avoid the high temperatures of the summer season and heavy rains of the mons oon seas on which are detrimental to the crop. In the northeast monsoon period agricultural activities such as ploughing, tilling, planting, fertilizing is at its peak and these activities are unfavorable to the beetles and hence low abundance, diversity and species richness was recorded during this season. Cattle dung is the main source of dung in the agriculture habitat of the region (Latha and Sabu, 2018; 2019). During northeast monsoon season while banana cultivation peaks, cattle is not allowed into the field which in turn lowers the dung resource availability for dung beetles, leading to low abundance, species richness and diversity of beetles. While in summer after harvesting banana, the vegetation is cut and domestic cattle is allowed to graze in the fields, and there is greater availability of dung resource for the dung beetles. 
Eight species all tunnelers showed significant seasonality. Caccobius meridionalis, Catharsius molossus, Copris repertus, Onthophagus furcillifer and $O$. manipurensis which showed peak abundance in summer can be considered as heliophiles, able to tolerate the high temperature and sunlight exposure of the summer season in the open agriculture habitat. Decades of anthropogenic disturbance that has heavily degraded the forests in the region has led to the establishment of heliophiles and synanthropic dung beetle species in the region that are able to survive in the summer season in the open agriculture habitat (Latha and Sabu, 2018; 2019). Copris repertus, Onthophagus pacificus, O. laevis, Paracopris cribratus, $P$. davisoni which showed peak abundance in southwest monsoon season are able to tolerate the heavy rains characteris tic of that period.

\section{CONCLUSION}

Dung beetles in the agriculture habitat responded differently to rainfall seasonality when compared to forest beetles in the same region. Agricultural practices affected dung beetle's response to seasonality. Northeast monsoon season with favourable climatic conditions showed low abundance, diversity and species richness. Agriculture activities did not provide favourable conditions for dung beetles in the field during the northeast monsoon period and also affected the availability of dung which led to the low species richness, abundance and diversity during that season.

\section{ACKNOWLEDGEMENT}

The University Grants Commission, India is acknowledged for the financial assistance, St. Josephs College, Devagiri, for the laboratory facilities; Vinod, Shiju, Nithya for technical as sistance.

\section{REFERENCES}

[1] Andresen E. (2005). Effects of season and vegetation type on community organization of Dung beetles in a tropical dry forest. Biotropica, 37: 291-300.

[2] Batista M.C., Lopes G da S., Marques L. J. P., Teodoro A. V. (2016). The dung beetle as semblage (Coleoptera: Scarabaeinae) is differently affected by land use and seasonality in northeastern Brazil. Entomotropica, 31(13): 95-104.

[3] Cambefort Y., Walter P. (1991). Dung beetles in Tropical forests in Africa. In: Hanski I. and Cambefort Y., editors. Dung beetle ecology, 198-210. Princeton University Press.

[4] Doube B.M. (1991). Dung beetles of South Africa. In: Hanski I. and Cambefort Y., editors.Dung Beetle Ecology, 133-155. Princeton University Press.
[5] Estrada A., Anzures A., Coates-Estrada R. (1999). Tropical rain forest fragmentation, howler monkeys (Alouatta palliata), and dung beetles at Los Tuxtlas, Mexico. American Journal of Primatology, 48: 253262.

[6] Halffter G. (1991). Historical and ecological factors determining the geographical distribution of beetles (Coleoptera: Scarabaeidae: Scarabaeinae). Folia Entomologica Mexicana, 82: 95-238.

[7] Hanski I., Cambefort Y. (1991). Resource partitioning. In: Hanski I. and Cambefort Y., editors. Dung Beetle Ecology, 330-349. Princeton University Press.

[8] Hanski I., Krikken J. (1991). Dung beetles in Tropical Forests in South-East Asia. In: Hanski I. and Cambefort Y., editors. Dung Beetle Ecology, 179-197. Princeton University Press.

[9] Jha, C. S., Dutt, C. B. S., Bawa, K. S. (2000). Deforestation and land use changes in the Westem Ghats, India. Current Science.79 (2): 231-238.

[10] Joy M.S. (1991). Keralathile Vanyajeevi sankethangal (Wild Life Reserves in Kerala). State Institute of Languages, Kerala.

[11] Kumar S. (1993). Survey and mapping of shola forests and grasslands in the Upper Nilgiri Plateau and assessment of human utilization of the vegetation. Report submitted to World Wild Fund for NatureIndia.

[12] Latha A., Unnikrishnan S. (2007). RBO driven campaign to preserve downstream ecological flows of a Western Ghats river. Accessed on March 10, 2010. www.riversymposium.com.

[13] Latha T., Sabu T.K. (2018). Dung beetle (Coleoptera: Scarabaeinae) community structure across forestagriculture habitat ecotone in South Western Ghats. International Journal of Environment, Agriculture and Biotechnology, 3(5) 1880-1890.

[14] Latha T. Sabu T.K. (2019) Effects of land use on dung beetle (Scarabaeinae) community structure in South Western Ghats. International Journal of Environment, Agriculture and Biotechnology, 4(1) 198-208.

[15] Latha T. (2019). Seasonal Activity of dung beetles (Scarabaeinae) in a forest in South Western Ghats. International Journal of Forest, Animal and Fisheries Research, 3(2)58-64.

[16] Nair S.C. (1991). The Southern Western Ghats- a biodiversity conservation plan. Indian National Trust for Art and Cultural Heritage, New Delhi, 92 pp.

[17] Nathan K. K. (2000). "Characteristics of Drought in Kerala, India". Drought Network News (1994-2001). 61. http://digitalcommons.unl.edu/droughtnetnews/61 
[18] Nichols E., Larsen T., Spector S., Davis A.L., Escobar F. (2007). Global dung beetle response to tropical forest modification and fragmentation: A quantitative literature review and metanalysis. Biological Conservation, 137: 1-19.

[19] Nichols E., Spector S., Louzada J., Larsen T., Amezquita, S., Favila M.E., The Scarabaeinae Research Network. (2008). Ecological functions and ecosystem services provided by Scarabaeinae dung beetles. Biological Conservation, 141: 1461-1474.

[20] Shahabuddin G., Prasad S. (2004). Assessing ecological sustainability of non-timber forest produce extraction: the Indian scenario. Conservation and Society. 2, 235-250.
[21] Venugopal K.S., Thomas S.K., Flemming A.T. (2012). Diversity and community structure of dung Beetles (Coleoptera: Scarabaeinae) as sociated with semi-urban fragmented agricultural Land in the Malabar coast in southern India. Journal of Threatened Taxa, 4(7): 26852692.

[22] Vinod K.V. (2009). Studies on the Systematics and Distribution of Dung Beetles (Scarabaeinae: Coleoptera) in the Forests and Agricultural Fields of Wayanad. Ph.D. Thesis, Forest Research Institute University.

[23] Walter P. (1985). Diurnal and nocturnal flight activity of Scarabaeine coprophages in tropical Africa. Revue internationale de géologie, de géographie et d'écologie tropicales, 9: 67-87.

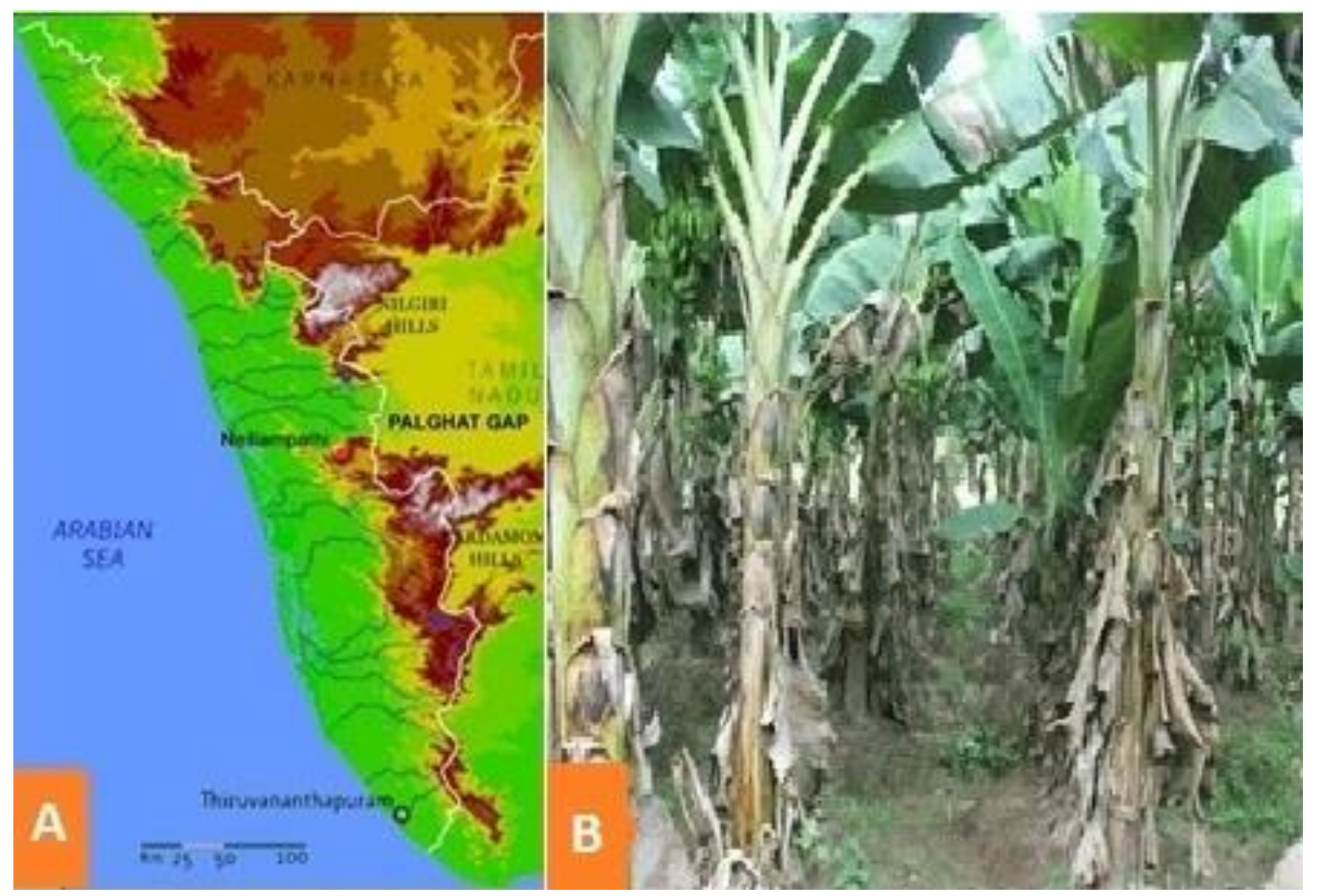

Fig. 1 (A) Study site Nelliampathi in South Western Ghats in Kerala; (B) Agriculture habitat in Nelliampathi. 
Table 1: Seasonal abundance (NEM=Northeast monsoon, $S=$ Summer, $S W M=$ Southwest monsoon); and seasonality ( $S E=$ Seasonal, $A S=$ Aseasonal, *=Seasonality not determined) ofdung beetle species in an agriculture habitat in Nelliampathi in South Western Ghats during the 2007-2008 study period.

\begin{tabular}{|c|c|c|c|c|}
\hline Species & NEM & $\mathrm{S}$ & SWM & Seasonality \\
\hline Caccobius gallinus & 0 & 5 & 0 & SE \\
\hline Caccobius meridionalis & 19 & 63 & 6 & $\mathrm{SE}$ \\
\hline Caccobius ultor & 0 & 0 & 3 & AS \\
\hline Catharsius molossus & 0 & 7 & 5 & SE \\
\hline Copris repertus & 0 & 10 & 17 & SE \\
\hline Liatongus indicus & 1 & 0 & 0 & $*$ \\
\hline Onitis subopacus & 0 & 1 & 0 & AS \\
\hline Onthophagus amphicoma & 1 & 2 & 0 & AS \\
\hline Onthophagus andrewesi & 1 & 0 & 0 & $*$ \\
\hline Onthophagus bronzeus & 0 & 1 & 1 & AS \\
\hline Onthophagus ensifer & 1 & 8 & 3 & AS \\
\hline Onthophagusfasciatus & 13 & 38 & 23 & AS \\
\hline Onthophagusfavrei & 0 & 2 & 3 & AS \\
\hline Onthophagus furcillifer & 5 & 28 & 11 & SE \\
\hline Onthophagus insignicollis & 0 & 0 & 2 & $\mathrm{AS}$ \\
\hline Onthophagus laevis & 0 & 0 & 4 & SE \\
\hline Onthophagus manipurensis & 0 & 8 & 0 & SE \\
\hline Onthophagus pacificus & 0 & 2 & 11 & $\mathrm{SE}$ \\
\hline Onthophagus porcus & 0 & 1 & 0 & $*$ \\
\hline Onthophagus rectecornutus & 0 & 0 & 1 & $*$ \\
\hline Onthophagus turbatus & 0 & 10 & 2 & AS \\
\hline Paracopris cribratus & 0 & 1 & 6 & SE \\
\hline Paracopris davisoni & 0 & 0 & 6 & SE \\
\hline Tibiodrepanus setosus & 3 & 7 & 0 & AS \\
\hline Tibiodrepanus sinicus & 0 & 0 & 1 & $*$ \\
\hline
\end{tabular}

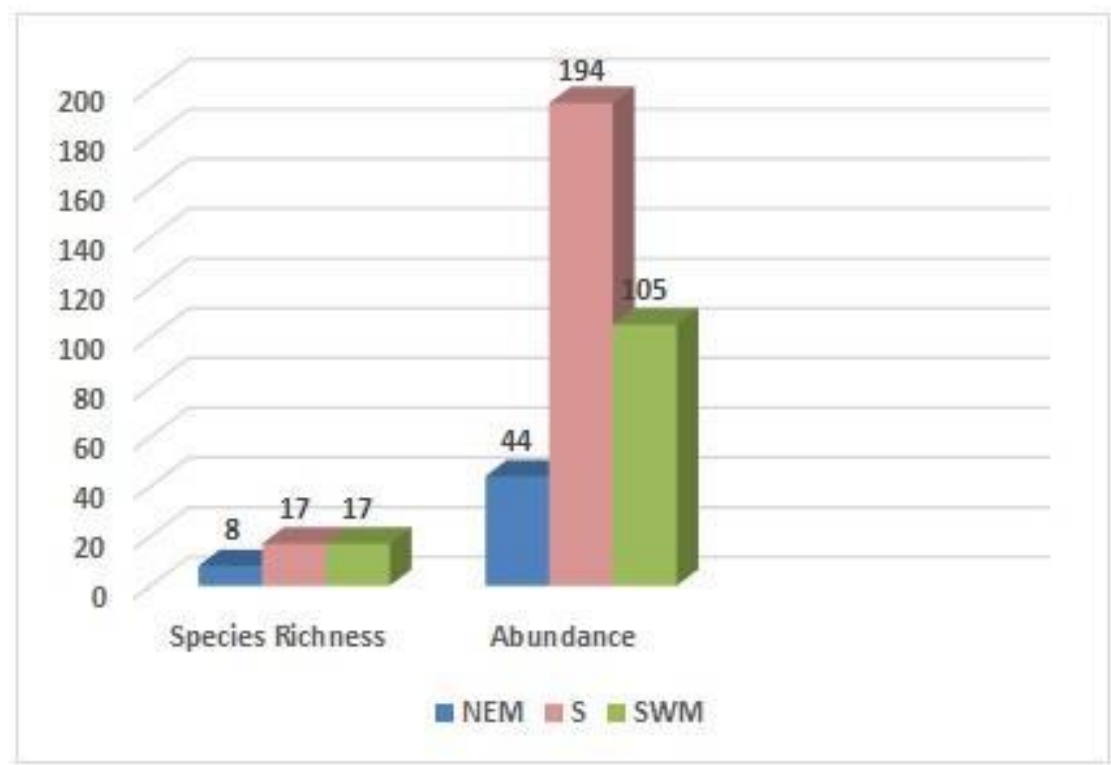

Fig. 2: Dung beetle species richness and abundance in northeast monsoon (NEM), summer (S) and southwest monsoon (SWM) seasons in an agriculture habitat in Nelliampathi in South Western Ghats during the 2007-2008 study period. 


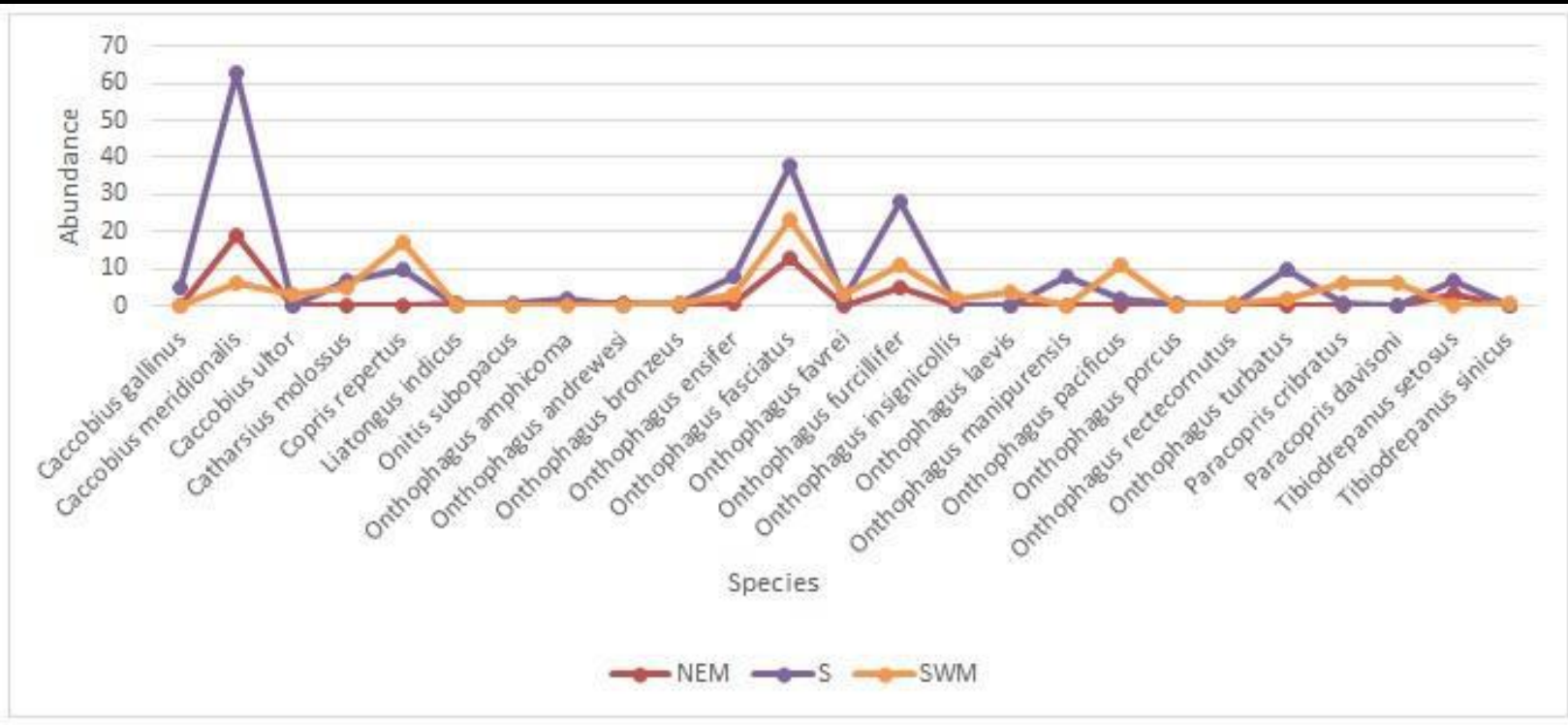

Fig. 3: Seasonal abundance of dung beetle species in an agriculture habitat in Nelliampathi in South Western Ghats during the 2007-2008 study period (NEM =northeast monsoon, $S=$ summer, SWM=southwest monsoon). 